\title{
Profitability analysis of winter vegetables production in a selected area of narshingdi district in Bangladesh
}

\author{
NY Chowdhuri ${ }^{1}$, S Haque ${ }^{2 *}$, SA Shammi ${ }^{3}$, A Jannat ${ }^{2}$, PR Sannyashi ${ }^{2}$ \\ ${ }^{1}$ Assistant Director, Bangladesh Bank, ${ }^{2}$ Department of Agricultural Economics, Faculty of Agricultural \\ Economics and Rural Sociology, Bangladesh Agricultural University, Mymensingh 2202, Bangladesh; ${ }^{3}$ Deputy \\ Manager, HR, Service Solutions Pvt. Ltd, Bangladesh
}

\begin{abstract}
The present study was designed to analyze the production, cost, return and profitability of three winter vegetables (brinjal, country bean and cabbage) production of three villages ofNarshingdi District in Bangladesh. To achieve the objectives, data were collected from 60 farmers. The sample farmers were selected through purposive sampling technique.The major findings of the study were: among the winter vegetables, cabbage production was more profitable. Per hectare profitability of growing vegetables from the viewpoints of individual farmers was measured in terms of gross return, gross margin and value addition. Per hectare gross costs of brinjal, country bean and cabbage production were Tk. 241277, Tk. 162337 and Tk. 204152 respectively, and per hectare average yields of brinjal, country bean and cabbage were estimated at 24175 kg/ha $15774 \mathrm{~kg} / \mathrm{ha}$, and $24707 \mathrm{~kg} / \mathrm{ha}$, respectively. Per hectare gross returns of brinjal, country bean and cabbage were Tk. 483500, Tk. 347028 and Tk. 494140, respectively. Per hectare net returns of brinjal, country bean and cabbage were Tk. 242223, Tk. 184691, and Tk. 289988, respectively. It shows that cost of production per hectare was higher for brinjal than for cabbage and country bean. The study also shows that per hectare yield, gross returns, gross margin, net return and benefit cost ratio of cabbage were higher than those of country bean and brinjal. Therefore, it is clear that cabbage production was most profitable among the three crops.
\end{abstract}

Key words: Profitability, winter vegetables, costs of production

Progressive Agriculturists. All rights reserved.

\section{Introduction}

Bangladesh has made substantial progress towards achieving its goal of food grain self-sufficiency. This achievement has been based on a substantial intensification of agriculture. Agricultural farming is one of the crucial rural activities in Bangladesh. Most of the people here depend on agriculture for the livelihood. Agriculture sector contributes about 19.29\% to GDP (Economic Review, 2011). The agriculture sector comprises crops, livestock, forestry and fisheries. Approximately 11.23 percent, 2.67 percent, 4.51 percent and 10.75 percent of the GDP was derived from crops, livestock, fisheries and forestry correspondingly (BER, 2010).Ensuring food security for the vast population of Bangladesh is directly associated with the agricultural development in the country. As we know, Bangladesh is one of the world's most densely populated countries with 150 million people, $26 \%$ of whom live below the national poverty line of US \$2 per day. In addition, child malnutrition rates are currently at $48 \%$, in condition that is tied to the low social status of women in Bangladeshi society. To alleviate poverty and malnutrition in our country it is necessary to increased production and consumption of nutritious and health-promoting vegetables. Moreover there is a great need for vegetable cultivation in a view 


\section{Profitability analysis of winter vegetables}

of increase in income, employment and reduce widespread malnutrition in Bangladesh.

A tropical location, fertile land, moisture rich loamy soil, makes Bangladesh one of the notable growers of a vast range of vegetables of impeccable quantity. However, commercial production of vegetable is getting momentum; and small and medium farmers with proper technical knowledge and skill are also coming forward increasingly to undertake this venture. On the other hand, Vegetables are rich in carbohydrate, protein, vitamins such as vitamin A, vitamin B, Vitamin C, niacin, riboflavin and thiamin and minerals like calcium and iron which makes human diet complete and balanced. They provide fiber necessary for digestion and health as well as combating malnutrition, curing nutritional disorders and diseases. In the year 2009-2010, national production of winter vegetables were 6.30 million tons and production area was 1.91 lakh hectares (BBS, 2010). Among the vegetables, brinjal, country bean and cabbage are the most common, popular and majorwinter vegetables in Bangladesh. But farmers' willingness is important to produce vegetables where they found vegetable production is not profitable as well. We know that profitability of a crop depends on yield, price of the product, cost of inputs and as well, farmers' management capacity. Any variation in any of the above factors obviously changes the profitability. Parvin (2008) found alternate rice and vegetables production were profitable from the viewpoint of marginal, small, medium and large farmers. Naher (2005) observed that produce vegetable and exporting it to other countries is more profitable than other crops.Hossain (1997)found that cucumber growers received the highest per hectare gross return, net return above full costs and cash costs and cabbage growers obtained the lowest per hectare gross return, net return above full costs and cash cost. Haque(2001)observed that in most of the vegetables production the MVP of human labour was greater than one and it was also significant implying that it was a very crucial input and there prevails a great chance to generate employment.

The increase in the production of rice and wheat, however, will not be sufficientto meet the food requirements of the growing population of Bangladesh. Food grain production led to adverse effect on the hectareage and production of vegetables. As a result, the people of Bangladesh are suffering from severe malnutrition. Addition of vegetables in the dietary menu is a must to maintain good health. Bangladesh is not self-sufficient in vegetables production. So, production of winter vegetables needs to be increased. The government of Bangladesh has given emphasis on vegetable production in the year-round to meet the nutritional and caloric need for the growing population and for increasing employment opportunities and income of farmers. Prior to giving emphasis on the production of winter vegetables, it requires relevant and adequate information on different aspects of production at farm level. For this reason, the present study makes an attempt to analyze and compare the relative profitability of selected vegetables. The study would identify the majorfactors that affect the yield of these vegetables. Therefore, the individual farmer would be benefited from this study for effective operation and management of their farms.

\section{Materials and Methods}

Selection of the study area is an important step for farm management study. The area, in which a farm business survey is to be made, depends on the particular purposes of the survey and possible cooperation from the farmers. Keeping in view the objectives, three villages from Narshindi district namely Brahmondi, Ghasirdia Kharia under Shibpurupazilla were purposively selected for data collection. A reasonable size of 60 representative samples(20 from each village) wasselected for the present study. In this study, a stratified random sampling technique was followed.

Descriptive statistical measures like sum, average, percentage etc. were used to find the crude association or variations between variables which has been presented in the form of tables.In this study, costs were measured in terms of variable and total cost basis. Per hectare profitability of growing vegetables from the viewpoints of individual farmers was measured in terms of gross return, gross margin and net return. The following profit (П) equation was 
developed to assess the net return of the vegetable producers:

$\Pi_{\mathrm{i}}=\mathrm{P}_{\mathrm{i}} \mathrm{Q}_{\mathrm{i}}-\mathrm{TCi}$

$=\mathrm{P}_{\mathrm{i}} \mathrm{Q}_{\mathrm{i}}-(\mathrm{VC}+\mathrm{FC})$

Where, $\Pi_{\mathrm{i}}=$ Profit from ith vegetables, $\mathrm{Q}_{\mathrm{i}}=$ Quantity of the ith product $(\mathrm{Kg}), \mathrm{P}_{\mathrm{i}=}$ Average price of ith vegetable $(\mathrm{Tk} . / \mathrm{Kg}), \mathrm{TC}=$ Total cost $\mathrm{Tk} . / \mathrm{Kg}$ of ith vegetables, $\mathrm{VC}=$ Variable cost, $\mathrm{FC}=$ Fixed cost, $\mathrm{i}$ $=1,2,3, \ldots$ $n$

To measure the factors affecting vegetables production, the stochastic frontier production function, independently proposed by AIGNER, LOVELL and SCHMIDT (1977) and WELISEN and van den BROECK (1977), have been used where an additional random error $\mathrm{V}_{\mathrm{i}}$ is added to the nonnegative random variable, $U_{i}$. The model can be expressed in the following logarithmic form:

In $\mathrm{Y}=\mathrm{b}_{0}+\sum_{i=1}^{k} \mathrm{~b}_{\mathrm{i}}$ In $\mathrm{X}_{\mathrm{i}}+\mathrm{V}_{\mathrm{i}}-\mathrm{U}_{\mathrm{i}}$

where $\mathrm{Y}$ is the frontier output, $\mathrm{b}_{0}=\ln \mathrm{a}, \mathrm{X}$ is physical input, $b_{i} s$ are the elasticities of $Y$ with respect to $\mathrm{X}, \mathrm{a}$ is intercept and $\varepsilon=\mathrm{V}_{\mathrm{i}}-\mathrm{U}_{\mathrm{i}}$ is a composed error term.

For calculating the costs and return,the costs items were classified into two groups: (i) variable cost, and (ii) fixed cost. Gross return was calculated simply by multiplying the total volume of output with per unit of price in the harvesting period.Gross margin calculation was done to have an estimate of the difference between total return and variable costs. It had been calculated by deducting total return over variable cost.Net return analysis was done by considering the fixed costs.Fixed costs of production are cost of rental value of land, interest on operating capital etc. Interest on operating capital (IOC) was determined by taking all costs incurred on various operations in the process of cultivatingbrinjal, country bean and cabbage. It was assumed that if the farmers borrowed the money from a bank, they had to pay interest at the same rate. It was estimated as: Interest on operating capital $=\mathrm{AI} \times \mathrm{i} \times \mathrm{t}$; Where, AI $=($ Total investment $) / 2 ; \mathrm{i}=$ Rate of interest; $\mathrm{t}=$ Period of crop cultivation (in month). The interest was charged at the rate of 10 percent per annum. The period considered for an enterprise ranged from the time of land preparation to the harvesting of the crop, i.e., 3 months of brinjal, country bean and cabbage production.

So, per hectare net return was determined by subtracting per hectare total cost (variable cost and fixed cost) of production from per hectare total return. The BCR is a relative measure, which was used to compare benefit per unit of cost. The BCR was estimated as a ratio of gross returns and gross costs as follows:

Benefit cost ratio $=\frac{\text { Gross benefit }}{\text { Gross cost }}$

\section{Results and Discussions}

Variable cost of brinjal, country bean and cabbage included the cost of all variable factors like human labour, land preparation, seeds, fertilizers (Urea, TSP, DAP, MP, Gypsum, Boron, Zinc), manure, irrigation water and insecticides. The prices of different inputs in the production period have been mentioned in table 1 . On the other hand, fixed cost was calculated for land use cost and interest on operating capital. On the return side, gross return, gross margin, net return and undiscounted benefit cost ratio (BCR) were determined. Table 2 shows per hectare costs and return of brinjal, country bean and cabbage production.

Table 1. The prices of different inputs in the production period

\begin{tabular}{|l|l|l|l|l|l|l|l|l|l|}
\hline Inputs & Seeds & Urea & TSP & DAP & MP & Gypsum & $\begin{array}{l}\text { Cow } \\
\text { dung }\end{array}$ & Boron & Zinc \\
\hline $\begin{array}{l}\text { Price } \\
\text { per kg. } \\
\text { (Tk.) }\end{array}$ & $\begin{array}{l}\text { Brinjal: Tk. 9000, } \\
\text { Country bean: Tk. 50 } \\
\text { and Cabbage: Tk. } \\
13000\end{array}$ & 20 & 35 & 34 & 28 & 25 & 0.75 & 80 & 35 \\
\hline
\end{tabular}

Source: Field survey, 2013 


\section{Profitability analysis of winter vegetables}

It has been found from Table 3 that cost of human labour covers a major share among all cost items for all crops. A comparison has been made to assess per hectare relative profitability of growing brinjal, country bean and cabbage (Table 2). The table shows that per hectare yield and gross returns of cabbage were higher than those of country bean and brinjal. On the other hand, cost of production per hectare was higher for brinjal than for cabbage and country bean. Table 5 also shows that gross margin, net return and benefit cost ratio of cabbage was higher followed by country bean and brinjal. From the above discussions, cabbage production was most profitable among three crops in the areas.

It has been found from Table 3 that the coefficient of human labour was positive and significant for brinjal and country bean. It was strange that farmers were using so much labour but still they need to use more labour. It may be the fact that whenever they get time, they are working though it was not necessary to work in the vegetable field. It seems that farmers need to allocate labour efficiently. Cost for land preparation is significant for all vegetables which mean that farmers need to plough the land for more time. The coefficient of seed shows that farmers need to use more seed. They may need to use quality seed. In Bangladesh, to get the quality seed is difficult. Therefore, in many cases, farmers sow low quality seeds two or three times and seed cost becomes higher.

Coefficient of urea shows two different types of results for two vegetables. It has been found that farmers apply higher amount of urea than their requirements but in case of cabbage, they had the opportunity to get more production by applying more urea fertilizer. Still it is a matter of question as Bangladeshi farmers like to apply more and more urea. It is needed to be checked whether they need to use more or they need to apply it timely, when urea is necessary for the crop. It has been found that farmers were using less amount of TSP than requirements and they thoughtthat it would be the opportunity to produce more vegetables by applying more TSP. In case of fertilizer use, very less no. of farmers behave rationally. In many cases, they only mean fertilizer as urea. To promote the use of balanced dose of fertilizer, government of Bangladesh has increased the subsidy of non-urea fertilizer since 2009. Like urea, the similar story is true for insecticide use in case of brinjal. It has been found that farmers spray insecticides 60-70 times in their brinjal field. Sometimes they were inspired by their neighbours who hang their pesticide container in their field. Sometimes, they even use the insecticide which was necessary for potato.

Along with production variables, some socioeconomic variables were also included in the model to check how these affect production. It has been found that educated, experienced and trained farmers were performing better. The result is expected and in line with other similar studies, not surprising and contradictory.

\section{Problems and solutions}

Farmers faced various problems in producing vegetables. Some of the major problems and constraints, which the farmers emphasized upon such as lack of capital, inadequate supply of good quality seeds, high prices of fertilizers, unavailability and high price of insecticides, attack by pests and diseases, vegetables damage by domestic animal, loss of production due to theft, marketing problems faced by the farmers, inadequate storage facilities, lack of marketing facilities, dominance of intermediaries etc. Out of those problems, about 70 per cent of farmers in the study area reported that they do not have enough capital. So, they produced vegetables only in limited quantities. The study also found that availability of good quality seeds was required by the farmers in the study area to sustain brinjal, country bean and cabbage production. Appropriate training facility and sufficient extension services are needed for the betterment of farmers. Therefore, it is suggested that apart from local and/or national market, positive steps should be taken to explore export markets so that the farmers can have more benefits from winter vegetable production of brinjal, country bean and cabbage. Thus, fair price of vegetables for farmers can be ensured and its sustainable production and growth could be maintained. 
Table 2. Comparative Cost and Return of Production for per hectare brinjal, country bean and cabbage

\begin{tabular}{|c|c|c|c|c|c|c|c|}
\hline \multirow[t]{2}{*}{ Items } & \multirow[t]{2}{*}{ Unit } & \multirow{2}{*}{\begin{tabular}{|c|} 
Brinjal \\
Quantity
\end{tabular}} & \multicolumn{3}{|l|}{ Country bean } & \multicolumn{2}{|c|}{ Cabbage } \\
\hline & & & Total & Quantity & Total & Quantity & Total \\
\hline A. Gross returns (i+ii) & Tk. & & 483500 & & 347028 & & 494140 \\
\hline i. Main product & $\mathrm{Kg}$ & 24175 & 483500 & 15774 & 347028 & 24707 & 494140 \\
\hline ii. By product & Tk. & - & - & & & & \\
\hline \multicolumn{8}{|l|}{ Variable cost } \\
\hline Human labour & $\begin{array}{l}\text { Man } \\
\text { day }\end{array}$ & 315 & $82019(42.70)$ & 141 & $88887(43.50)$ & 392 & $101920(55.32)$ \\
\hline Animal labour/ Power tiller & Tk. & - & & & & - & $3027(4.21)$ \\
\hline Land preparation & Tk. & & 11708(6.09) & - & $3000(3.45)$ & & \\
\hline Seeds & $\mathrm{Kg}$ & 1.71 & $15446(4.68)$ & 41.8 & $2090(8.34)$ & 0.3 & $3900(1.81)$ \\
\hline Urea & $\mathrm{Kg}$ & 278 & $5563(2.89)$ & 48.75 & $975(2.26)$ & 377 & $7540(4.26)$ \\
\hline TSP & $\mathrm{Kg}$ & 236 & $8274(4.65)$ & 81.71 & $3000(3.95)$ & 245 & $8575(4.87)$ \\
\hline DAP & $\mathrm{Kg}$ & 122 & 4293(4.25) & 23.41 & 796(11.41) & 250 & $8500(4.73)$ \\
\hline MP & $\mathrm{Kg}$ & 64 & $1800(2.39)$ & 53.57 & $1500(2.03)$ & 260 & $4680(2.50)$ \\
\hline Gypsum & $\mathrm{Kg}$ & 13 & $337(0.77)$ & 5.04 & $126(0.11)$ & 100 & $1000(0.42)$ \\
\hline Cow dung & Kg & 15248 & $11436(0.71)$ & 7657 & 5743(2.72) & 6500 & $4890(0.43)$ \\
\hline Oil cake & Kg & & & & & 40 & $880(0.31)$ \\
\hline Boron & Kg & 36 & $2948(0.53)$ & & & & \\
\hline Zinc & Kg & 135 & $5287(0.53)$ & & & & \\
\hline Irrigation charge & Tk. & & $14377(6.70)$ & & & & 6739(3.34) \\
\hline Insecticides & Tk. & & 28580(2.03) & & 11884(1.38) & & $2500(1.82)$ \\
\hline Others costs & Tk. & & & & $12875(4.62)$ & & \\
\hline B. Total variable cost & Tk. & & 192068(84.16) & & 130876(83.77) & & 154152(84.02) \\
\hline Land use cost & Tk. & & $44909(3.23)$ & & 29940(3.66) & & $45000(3.38)$ \\
\hline Interest on operating capital & Tk. & & $4298(12.62)$ & & 1521(12.57) & & $5000(12.60)$ \\
\hline C. Total fixed cost & Tk. & & 49207(15.84) & & $31461(16.23)$ & & $50000(15.98)$ \\
\hline D. Gross cost $(B+C)$ & Tk. & & $241277(100)$ & & 162337(100) & & $204152(100)$ \\
\hline E. Gross margin(A-B) & Tk. & & 292432 & & 216152 & & 339988 \\
\hline F. Net returns (A-D) & Tk. & & 242223 & & 184691 & & 289988 \\
\hline G. BCR (undiscounted) & & & 2.003 & & 2.14 & & 2.42 \\
\hline
\end{tabular}

Source: Field Survey, 2013. Figures in the bracket indicate the percentage of total cost 
Table 3. Estimated Co-efficient and their related statistics of production function for the selected vegetables

\begin{tabular}{|c|c|c|c|}
\hline Regression variable & Brinjal & Country bean & Cabbage \\
\hline \multicolumn{4}{|l|}{ Production variables } \\
\hline Intercept & $\begin{array}{l}17.303^{* * *} \\
(2.889)\end{array}$ & $\begin{array}{l}4.188^{*} \\
(1.882)\end{array}$ & $\begin{array}{l}9.930^{* * *} \\
(4.494)\end{array}$ \\
\hline Human labour & $\begin{array}{l}0.611^{* *+} \\
(2.648)\end{array}$ & $\begin{array}{l}0.367^{\text {*** }} \\
(2.885)\end{array}$ & $\begin{array}{l}0.127 \\
(0.787)\end{array}$ \\
\hline Land preparation & $\begin{array}{l}0.428^{* * *} \\
(2.849)\end{array}$ & $\begin{array}{l}0.691^{* * *} \\
(4.610)\end{array}$ & $\begin{array}{l}0.286^{* *} \\
(2.355)\end{array}$ \\
\hline Seed/ Seedling & $\begin{array}{l}0.058 \\
(0.206)\end{array}$ & $\begin{array}{l}0.051^{* *} \\
(2.048)\end{array}$ & $\begin{array}{l}0.068^{* *} \\
(2.429)\end{array}$ \\
\hline Manure & $\begin{array}{l}-0.007 \\
(-0.383)\end{array}$ & $\begin{array}{l}0.002 \\
(1.267)\end{array}$ & $\begin{array}{l}-0.003 \\
(-0.247)\end{array}$ \\
\hline Urea & $\begin{array}{l}-0.525^{*} \\
(-1.714)\end{array}$ & $\begin{array}{l}0.025 \\
(0.147)\end{array}$ & $\begin{array}{l}0.200^{*} \\
(1.820)\end{array}$ \\
\hline TSP & $\begin{array}{l}0.056^{*} \\
(1.926)\end{array}$ & $\begin{array}{l}0.234^{*} \\
(1.966)\end{array}$ & $\begin{array}{l}0.276^{*} \\
(1.79)\end{array}$ \\
\hline MoP & $\begin{array}{l}-0.022 \\
(-0.127)\end{array}$ & $\begin{array}{l}-0.317 \\
(-.812)\end{array}$ & $\begin{array}{l}0.002 \\
(0.167)\end{array}$ \\
\hline Insecticides & $\begin{array}{l}0.387^{*} \\
(1.778)\end{array}$ & $\begin{array}{l}-0.009 \\
(-0.409)\end{array}$ & $\begin{array}{l}-0.017 \\
(-1.151)\end{array}$ \\
\hline Irrigation & $\begin{array}{l}0.093 \\
(-0.266)\end{array}$ & $\begin{array}{l}0.103 \\
(1.066)\end{array}$ & $\begin{array}{l}0.200^{*} \\
(1.820)\end{array}$ \\
\hline \multicolumn{4}{|l|}{ Efficiency variables } \\
\hline Education & $\begin{array}{l}0.125^{*} \\
(1.757)\end{array}$ & $\begin{array}{l}0.047 \\
(0.991)\end{array}$ & $\begin{array}{l}0.276^{*} \\
(1.79)\end{array}$ \\
\hline Experience & $\begin{array}{l}0.103 \\
(1.207)\end{array}$ & $\begin{array}{l}0.113^{*} \\
(1.968)\end{array}$ & $\begin{array}{l}0.002 \\
(0.167)\end{array}$ \\
\hline Training & $\begin{array}{l}0.059^{* *} \\
(2.469)\end{array}$ & $\begin{array}{l}0.098^{*} \\
(1.688)\end{array}$ & $\begin{array}{l}-0.017 \\
(-1.151)\end{array}$ \\
\hline $\mathrm{R}$ & 0.612 & 0.89 & 0.59 \\
\hline F-values & $2.344^{* * *}$ & $6.653^{* * *}$ & $3.021^{* * *}$ \\
\hline Returns to scale & 1.37 & 1.41 & \\
\hline
\end{tabular}

Source: Field Survey 2013.

'***', '**' and '*' indicates $1 \%, 5 \%$, and $10 \%$ level of significance

Figures in the brackets indicate the standard error.

\section{Conclusion}

On the basis of above discussions, it could cautiously be concluded that the cultivation of brinjal, country bean and cabbage was profitable. However, cultivation of cabbage was the most profitable among three vegetables. Nevertheless, cultivation of brinjal and country bean would also help farmers to increase their net returns.It is no doubt that brinjal, country bean and cabbage can play an important role in earning cash money. In spite of the problems and constraints in brinjal, country bean and cabbage production, farmers in the study area are still now producing these vegetables. Because brinjal, country bean and cabbage are profitable crops and their method of cultivation is easy. Moreover, they are labour intensive. The management practices of 
selected vegetable enterprises in the study area were not found efficient enough. Farmers were not known about the application of inputs in right time with right doses. Consequently, they made over or under use of some inputs. Thus, well planned management training in accordance with their problems, needs,

\section{References}

BER (2011). Bangladesh Economic Review, Economic Advisory Section, Department of Finance, Ministry of Finance, Bangladesh.

BBS (2010). Yearbook of Agricultural Statistics of Bangladesh, Bangladesh Bureau of Statistics, Statistical Division, Ministry of goals and resource base can lead to viable production practices and sustainable income from brinjal, country bean and cabbage cultivation in commercial scale production.

Planning, Government of the People's Republic of Bangladesh, Dhaka.

Fahmida A (2006). Economics of some selected winter vegetables production in area of TrishalUpazila in Mymensingh District. M. S. Ag. Econ.thesis, Bangladesh Agricultural University, Mymensingh. 